\title{
Comparative Evaluation of the Efficacy of some Comprehensive Herbal Regimen for the Treatment of Repeat Breeding in Water Buffaloes
}

\author{
K. Jyothi ${ }^{1}$, Y. V. Pridhvidhar Reddy ${ }^{1}$, K. Sai Gunaranjan ${ }^{1}$, T. Nagendra Reddy ${ }^{2}$, \\ Sunidhi $^{3}$, K. Ravikanth ${ }^{3}$ and Bhaskar Ganguly ${ }^{3 *}$ \\ ${ }^{1}$ Department of Gynecology and Obstetrics, ${ }^{2}$ Department of Veterinary Microbiology, College \\ of Veterinary Science, Proddatur, Andhra Pradesh, 516360, India \\ ${ }^{3}$ Research \& Development Unit, Ayurvet Limited, Baddi, Himachal Pradesh, 173205, India \\ *Corresponding author
}

\section{Keywords}

Uterine cleanser,

Estrus inducer,

Repeat breeding,

Buffalo, Herbal

treatment

Article Info

Accepted:

15 December 2019

Available Online:

20 January 2020

\section{A B S T R A C T}

A study was undertaken to compare the efficacy of combinations of different brands of herbal uterine cleansers, estrus inducers and mineral supplements in the treatment of repeat breeding water buffaloes. Thirty she-buffaloes with a history of repeat breeding were randomly assigned to either of five equal groups. Group T0 served as untreated control, Group T1 was treated with combination of Exapar bolus (M/s Ayurvet Limited, Baddi) and Janovacapsule (M/s Ayurvet Limited, Baddi). Group T2 was treated with AV/UTB/26 bolus (M/s Ayurvet Limited, Baddi) and AV/OIP/22 powder (M/s Ayurvet Limited, Baddi). Mintrus caplet (M/s Ayurvet Limited, Baddi) was administered for 20 days from the initiation of treatment in both groups T1and T2.Group T3 was treated with a combination of Brands A, B and C. Group T4 was treated with a combination of Brands X, Y and Z. The percent conception rates were $33.33,50$ and 66.67 in Groups T0, T4, and $\mathrm{T} 1=\mathrm{T} 2=\mathrm{T} 3$ respectively. The number of services per conception was lower in Group T2 and T3 (1.25) as compared to Group T4 (1.33), Group T1 (1.5) and Group T0 (3.0). The number of bacterial colonies counted in cervical discharges collected before and after treatment reveals significantly reduced counts after following herbal treatments. It was concluded that reproductive performance was significantly improved after using combined therapy with herbal drugs.

\section{Introduction}

Of all the domesticated animals, the buffalo has the greatest unexplored potential for the development of milk yield, meat production and work output (Cockril, 1974). The buffalo plays a prominent role in rural economy, providing milk, meat and draft work-force (Hoffpauir, 1982). The increasing interest in buffalo rearing is primarily due to more desirable composition of buffalo milk in comparison to cow milk with regard to high 
milk fat content but low in cholesterol, higher total solids, SNF, proteins, calcium, phosphorus and calories per unit (Singh et al., 2000). Reproductive efficiency is the primary factor affecting productivity and the most important and commonly encountered subfertile conditions in buffalo that plays a vital role in dairy economics is repeat breeding (Saraswat et al., 2016). The repeat breeding syndrome is defined as a condition in which dairy animals have a regular estrous cycle and appear normal on superficial clinical examination but fail to conceive following three or more breeding (Bartlett et al., 1986). In spite of good progress made, the causes of conception failure are largely not well understood and repeat breeding remains the biggest problem of the dairy industry.

The present clinical trial was conducted to compare the efficacy of some herbal preparations in repeat breeding conditions in buffaloes.

\section{Materials and Methods}

The present study was undertaken in and around Proddatur, Kadapa district, Andhra Pradesh, over a period of six months. Thirty she-buffaloes identified with a history of repeat breeding were randomly allocated to control and four treatment groups treated with different herbal regimens as shown in Table 1 below:

Parameters such as post-treatment days for estrus induction, number of services per conception, nature of discharge in first posttreatment estrus (physical examination), random post-treatment microbiological examination of discharge before and after treatment and post-treatment conception rate were studied. Cervical mucus samples were collected taking all possible sterile precautions and the aspirated mucus was then studied in respect of its cleanliness and transparency. Ten random samples of cervical mucus were subjected for bacterial count and bacterial colonies were cultured in Muller Hinton agar, blood agar, and nutrient agar at $37^{\circ} \mathrm{C}$ for 24 to 48 hours and the growth was assessed based on the number of colonies. Standard statistical procedure was applied to test the various parameters.

\section{Results and Discussion}

The conception rate was $33.33 \%(2 / 6)$ in Group T0, 66.67\% (4/6) in group T1, T2 and $\mathrm{T} 4$ respectively and $50 \%(3 / 6)$ per cent in group T4. T1, T2 and T4 protocols showed equal and higher conception rates when compared with controls. Days for estrus induction after initiation of treatment showed no significant difference between protocols as the repeat breeder buffaloes showed regular cyclicity. Average number of services per conception was 1.25 for $\mathrm{T} 2$ and $\mathrm{T} 3$ which was lowest when compared with T4 (1.33), T1 (1.5) and T0 (3.0). The nature of discharge during first estrus post-treatment was clear in $50 \%$ of animals in T1, T2 and T4, 33.33\% in $\mathrm{T} 3$ and $16.66 \%$ in T0 (Table 2).

The number of bacterial colonies counted in cervical discharges collected before and after treatment revealed significantly reduced counts after following herbal treatments (Table 3). The cervical samples of 10 repeat breeder buffaloes were subjected to bacteriological examination randomly to isolate microorganisms. All ten animals were found to be positive for microorganisms. 50\% of these animals showed single bacterial isolates and rest samples possessed mixed infections. Bacilli were the predominant organisms to be isolated followed by Gram negative organisms, streptococci, staphylococci and E.coli. 
Table.1 Treatments assigned to different groups under the study

\begin{tabular}{|c|c|}
\hline Group & Treatment \\
\hline T0 & No treatment \\
\hline \multirow[t]{3}{*}{ T1 } & Exapar $^{\mathrm{IM}}$ bolus @ 4 boli/day orally for 5 days (days $1-5$ of parturition) \\
\hline & Janova $^{\mathrm{IM}}$ capsule @ 3 cap/day for 2 days (days 6 and 7 ) \\
\hline & Mintrus ${ }^{\circledR}$ Caplet @ 1 caplet daily for 20 days (0-20) \\
\hline \multirow[t]{3}{*}{ T2 } & AV/UTB/26 bolus @ 2 boli/day for 5 days (days $1-5$ of parturition) \\
\hline & AV/OIP/22 powder @ 200g/day for two days (days 6and 7) \\
\hline & Mintrus ${ }^{\circledR}$ Caplet @ 1 caplet daily for 20 days $(0-20)$ \\
\hline \multirow[t]{3}{*}{$\mathbf{T 3}$} & $\begin{array}{l}\text { Brand A @ } 200 \mathrm{ml} \text { on the first day, followed by single } 100 \mathrm{~mL} \text { dose once daily for next } \\
3 \text { days }\end{array}$ \\
\hline & Brand B @ 3cap/day for 2 days $\left(\right.$ day $6^{\text {th }}$ and $\left.7^{\text {th }}\right)$ \\
\hline & Brand C@1 tab daily for 20 days \\
\hline \multirow[t]{3}{*}{ T4 } & $\begin{array}{l}\text { Brand X @ } 200 \mathrm{~mL} \text { on the first day, followed by } 100 \mathrm{~mL} \text { for } 3 \text { consecutive days }\left(1^{\text {st }} \text { day }\right. \\
\text { to } 4^{\text {th }} \text { day) }\end{array}$ \\
\hline & Brand Y @ 2 boli once daily orally, for 3 consecutive days $\left(5^{\text {th }}\right.$ and $6^{\text {th }}$ day) \\
\hline & Brand Z @ 1 caplet orally for 10 consecutive days \\
\hline
\end{tabular}

Table.2 Reproductive parameters in repeat breeder buffaloes treated with herbal protocols

\begin{tabular}{|c|c|c|c|c|c|c|}
\hline S.No. & Particulars & \multicolumn{5}{|c|}{ Group } \\
\hline $\mathbf{1 .}$ & $\begin{array}{c}\text { Conception } \\
\text { Rate(\%) }\end{array}$ & 33.33 & 66.67 & 66.67 & 66.67 & 50.00 \\
\hline $\mathbf{2 .}$ & $\begin{array}{c}\text { No. of days for } \\
\text { onset of estrus }\end{array}$ & $25.0 \pm 3.51^{\mathrm{NS}}$ & $21.80 \pm 1.24^{\mathrm{NS}}$ & $21.0 \pm 0.68^{\mathrm{NS}}$ & $20.33 \pm 1.05^{\mathrm{NS}}$ & $21.40 \pm 0.81^{\mathrm{NS}}$ \\
\hline $\mathbf{3 .}$ & $\begin{array}{c}\text { No. of services } \\
\text { per conception }\end{array}$ & 3.00 & 1.50 & 1.25 & 1.25 & 1.33 \\
\hline $\mathbf{4 .}$ & $\begin{array}{c}\text { Animals } \\
\text { showing clear } \\
\text { mucus } \\
\text { discharge (\%) }\end{array}$ & 00.00 & 50.00 & 50.00 & 33.33 & 50.00 \\
\hline
\end{tabular}

Means bearing same superscript are statistically non-significant (NS) (p>0.05)

Table.3 Mean $( \pm$ SE) bacterial colony counts (in thousands) in repeat breeder buffaloes treated with herbal protocols

\begin{tabular}{|c|c|c|c|c|c|}
\hline Time of sample collection & \multicolumn{5}{|c|}{ Group } \\
\cline { 2 - 7 } & T0 & T1 & T2 & T3 & T4 \\
\hline Before treatment & $838 \pm 659^{\mathrm{a}}$ & $397 \pm 56^{\mathrm{a}}$ & $135 \pm 15.5^{\mathrm{a}}$ & $720 \pm 80^{\mathrm{a}}$ & $623 \pm 65.2^{\mathrm{a}}$ \\
\hline After treatment & $36.1 \pm 6.0^{\mathrm{a}}$ & $0.16 \pm 0.05^{\mathrm{b}}$ & $0.21 \pm 0.021^{\mathrm{b}}$ & $0.34 \pm 0.09^{\mathrm{b}}$ & $0.14 \pm 0.01^{\mathrm{b}}$ \\
\hline
\end{tabular}

Means bearing different superscripts differ significantly within rows $(\mathrm{p}<0.05)$ 
Repeat breeding in dairy animals causes tremendous economic losses to the farmers and to the nation by decreasing milk yield, the number of calves produced and by increasing culling rate. Many hormonal preparations like $\mathrm{GnRH}$, eCG, and progesterone alone or in combination have been tried on infertile animals to restore the fertility of dairy animals, but the results of hormonal treatments for infertility are unsatisfactory. The major constraints in the use of various hormonal preparations are high cost and nonavailability of commercial preparations with ease. Indiscriminate use of antibiotics for treatment of uterine infections has lead to emergence of resistance strains. As a result of this the attention is now moving towards the herbal formulations (Hemiaiswarya et al., 2008).

Higher conception rate $(66.67 \%)$ was recorded in T1, T2 and T3 groups when compared with T4 group and control. The number of services required per conception was significantly less in the groups T4, T3, T2 and group T1 as compared to the control group T0. The no. of animals exhibiting clear discharge was high in the group T1, T2 and T4 as compared to the control group T0. The bacterial colony count after treatment was significantly reduced in groups T1, T2, T3 and T4 as compared to the control group T0.

Dhakal (1999) recorded expulsion of placenta in 100 percent animals with conception rate of $72 \%$ vs. $40 \%$ in buffaloes and $55 \%$ vs. $25 \%$ in cows following use of Exapar. Similarly, Gautam et al., (2005) and Thakur et al., (2013) reported a significant positive effect on expulsion of placenta, cessation of lochial discharge and uterine involution in dairy animals following use of Exapar. Sahatpure et al., (2016) reported estrus response of $66.67 \%$ and conception rate of $75 \%$ when they used Mintrus and Estrofarm powder. Average number of AI required in Hadiya et al.,
(2015) study was 2 for repeat breeding in Jaffarabadi buffaloes and $25 \%$ was the conception rate for Exapar, Janova and Mintrus protocol and in the present study services per conception was 1.5 and conception rate was $66.67 \%$ respectively and the higher performance in the present study might be due to nutrition and environmental factors.

The improvement in reproductive performance in herbal drugs treated animals can be attributed to Citrullus colocynthis, a constituent ingredient of AV/OIP/22 which is a rich source of flavonoids (Benariba et al., 2013), isovitexin (Akhzari et al., 2015), cucurbitacin (Hatam et al., 1989) and caffeic acid (Shokrzadeh et al., 2013). The improvement in the conception rates might be due to caffeic acid which is known to inhibit nuclear factor kappa B (Akyol et al., 2015), a transcription factor which brings about changes in m-RNA synthesis and have a negative effect on reproductive performance (Manimaran et al., 2016). Presence of isovitexin may also have played a significant role in bolstering reproductive parameters as it is known to possess free radical scavenging activity (Khole et al., 2016). Parmar et al., (2017) concluded that oral administration of $\mathrm{AV} / \mathrm{UTB} / 26$ indicated for the purpose of uterine cleansing was found to be highly effective in reducing the instances of retention of placenta, decreasing the time for involution and increasing the conception rate.

In the present investigation, bacterial colony counts after treatment with different herbal protocols were significantly decreased and enhanced the conception rate by creating a congenial environment in the uterus for the survival of embryo.

In conclusion, reproductive performance was significantly improved after using combined therapy with herbal drugs. Repeat breeder 
buffaloes performed well after herbal treatment protocols with significant reduction in bacterial colony counts and optimum conception rates obtained with group $\mathrm{T} 1, \mathrm{~T} 2$ and T3. The reliance on cheap, efficacious and scientifically-proven, traditional plantbased drugs would add substantially to the dairy economy.

\section{References}

Akhzari, M., Mirghiasi, S.M., Vassaf, M., Bidgoli, M.S.M. and Tari, Z.S., 2015. The effect of Citrullus colocynthis on the reduction of inflammatory agents in osteoarthritis. Mol Biol4, 147.

Akyol, S., Akbas, A., Butun, I., Toktas, M., Ozyurt, H., Sahin, S. and Akyol, O., 2015. Caffeic acid phenethyl ester as a remedial agent for reproductive functions and oxidative stress-based pathologies of gonads. Journal of Intercultural Ethnopharmacology, 4(2), p.187.

Bartlett, P.C., Kirk, J.H. and Mather, E.C., 1986. Repeated insemination in Michigan Holstein-Friesian cattle: Incidence, descriptive epidemiology and estimated economic impact. Theriogenology, 26(3), pp.309-322.

Benariba, N., Djaziri, R., Bellakhdar, W., Belkacem, N., Kadiata, M., Malaisse, W.J. and Sener, A., 2013. Phytochemical screening and free radical scavenging activity of Citrullus colocynthis seeds extracts. Asian Pacific journal of tropical biomedicine, 3(1), pp.35-40.

Mason, I.L. and Cockrill, W.R., 1974. The husbandry and health of the domestic buffalo. No. SF213 C6, FAO, Rome.

Dhakal, I.P., 1999. Efficacy of Exapar for the expulsion of placenta and as uterine tonic in cows and buffaloes. Indian Journal of Animal Reproduction, 20(1), pp.33-34.
Gautam, R.P., Tiwari, R.P., Koley, K.M. and Hore, S.K., 2005. The Exapar in induction of uterine contraction in vitro and expulsion of fetal membranes in buffaloes. Indian Journal of Animal Reproduction, 26(2), pp.126-128.

Hadiya, K.K. and Ravikanth, K., Adarsh, and Reothia, A. 2015. Efficacy of Exapar, Janova and Mintrus (EJM) in the treatment of various reproductive disorders in Jaffrabadi buffaloes. International Journal of Advanced Research, 3(9), pp.1213-1216.

Hatam, N.A., Whiting, D.A. and Yousif, N.J., 1989. Cucurbitacin glycosides from Citrullus colocynthis. Phytochemistry, 28(4), pp.1268-1271.

Hemaiswarya, S., Kruthiventi, A.K. and Doble, M., 2008. Synergism between natural products and antibiotics against infectious diseases. Phytomedicine, 15(8), pp.639-652.

Hoffpauir, R., 1982. The water buffalo: India's other bovine. Anthropos, pp.215238.

Khole, S., Panat, N.A., Suryawanshi, P., Chatterjee, S., Devasagayam, T.P.A. and Ghaskadbi, S., 2016. Comprehensive Assessment of Antioxidant Activities of Apigenin Isomers: Vitexin and Isovitexin. Free Radicals \& Antioxidants, 6(2), pp.155166.

Manimaran, A., Kumaresan, A., Jeyakumar, S., Mohanty, T.K., Sejian, V., Kumar, N., Sreela, L., Prakash, M.A., Mooventhan, P., Anantharaj, A. and Das, D.N., 2016. Potential of acute phase proteins as predictor of postpartum uterine infections during transition period and its regulatory mechanism in dairy cattle. Veterinary world, 9(1), pp.91-100.

Parmar, S.V., Borthakur, A., Yadav, V. and Ravikant, K. (2017)Evaluation of efficacy of polyherbal uterine cleanser 
$\&$ restorative products for treatment of retained placenta cases in cattle. International Journal of Current Research, 9(07), pp. 54296-54298.

Sahatpure, S., Ravikanth, K., Maini, S. and Adarsh, P. (2016). Ovarian response after treatment with herbal oestrus inducer and trace mineral supplement in postpartum anoestrus in crossbreed cows. International Journal of Advanced Research, 4(7), 2069-2072.

Saraswat, C.S. and Purohit, G.N., 2016. Repeat breeding: Incidence, risk factors and diagnosis in buffaloes. Asian Pacific Journal of Reproduction, 5(2), pp.87-95.

Shokrzadeh, M., Chabra, A., Naghshvar, F. and Ahmadi, A., 2013. The mitigating effect of Citrullus colocynthis (L.) fruit extract against genotoxicity induced by cyclophosphamide in mice bone marrow cells. The Scientific World Journal, 2013.

Singh, J., Nanda, A.S. and Adams, G.P., 2000. The reproductive pattern and efficiency of female buffaloes. Animal Reproduction Science, 60, pp.593-604.

Thakur, A., Ravikanth, K., Maini, S., Patil, A.D., Deshmukh, A.A. and Patil, A.D., 2013. Management of post parturient reproductive disorders in dairy animals with herbal uterine cleanser Exapar-N. Advance Research in Pharmaceuticals and Biologicals, 3, pp.517-519.

\section{How to cite this article:}

Jyothi, K., Y. V. Pridhvidhar Reddy, K. Sai Gunaranjan, T. Nagendra Reddy, Sunidhi, K. Ravikanth and Bhaskar Ganguly. 2020. Comparative Evaluation of the Efficacy of some Comprehensive Herbal Regimen for the Treatment of Repeat Breeding in Water Buffaloes. Int.J.Curr.Microbiol.App.Sci. 9(01): 2116-2121. doi: https://doi.org/10.20546/ijcmas.2020.901.240 